Aljoša Šestanović

Bojan Tomic **

Dolores Pušar Banović ${ }^{* * *}$
JEL klasifikacija: G30, G32, M40

Prethodno priopćenje

https://doi.org/10.32910/ep.72.6.5

\title{
MEĐUZAVISNOST RENTABILNOSTI I LIKVIDNOSTI PRIMJENOM PANEL VAR MODELA
}

Cilj istraživanja je, empirijskom konfirmacijom, utvrditi postojanje međuzavisnosti rentabilnosti i likvidnosti. Uzorak obuhvaća dvadeset nefinancijskih društava uvrštenih u barem jedan od dioničkih agregatnih ili sektorskih indeksa Zagrebačke burze. Panel podatci obuhvaćaju vremensko razdoblje od devet godina, počevši od 2009. godine do zaključno s obuhvatom 2017. godine. Istraživanje međusobnog kauzaliteta provedeno je Grangerovim testom uzročnosti prilagođenog panel formulaciji podataka. U radu se koristi model panel vektorske autoregresije u sklopu koje je obrađena analiza strukture modela: ortogonalna dekompozicija varijanci prognostičkih pogrešaka i analiza ortogonalne funkcije impulsnih odziva. Rezultati pokazuju značajnu uzročnost varijabli rentabilnosti (prinos na ukupnu imovinu i prinos na vlastiti kapital) na koeficijente tekuće i ubrzane likvidnosti. S druge strane, nije utvrđena značajna uzročnost koeficijenata likvidnosti na varijable rentabilnosti. Rezultati su u skladu s očekivanjima iz financijske teorije prema kojoj postojanje značajne likvidnosti u društvu per se ne znači i značajan utjecaj na varijable rentabilnosti. Istraživanje je provedeno na ograničenom uzorku burzovno kotiranih društva na Zagrebačkoj burzi, što s obzirom na rezultate ovog istraživanja, sugerira provedbu sličnih istraživa-

* A. Šestanović, dr.sc., CFA, Viši predavač, EFFECTUS Visoko učilište (e-mail: asestan@ effectus.com.hr).

** B. Tomić, univ.spec.oec., Viši predavač, EFFECTUS University College for Law and Finance (email: bojan.tomic2@gmail.com).

*** D. Pušar Banović, PhD, Profesor visoke škole, RRiF Visoka škola za financijski menadžment (email: dolores@ rrif.hr). Rad je primljen u uredništvo 29.09.2019. godine, a prihvaćen je za objavu 25.05.2020. godine. 
nja na širem uzorku društava uvrštenih na inozemnim burzama radi daljnje verifikacije rezultata. Originalnost istraživanja leži u sveobuhvatnoj sistematizaciji radova koji su istraživali kauzalnost profitabilnosti (i rentabilnosti) $i$ likvidnosti, te izvornom pristupu testiranju međusobnih uzročnosti varijabli likvidnosti i rentabilnosti koristeći kompleksnije alate statističke analize.

Ključne riječi: rentabilnost, profitabilnost, likvidnost, prinos na vlastiti kapital, prinos na ukupnu imovinu, panel var model

\section{UVODNA RAZMATRANJA}

Profitabilnost (u širem značenju) i likvidnost čine okosnicu financijskog upravljanja u poslovnim subjektima. Profitabilnost se šire definira kao sposobnost društva da ostvaruje profit u odnosu na neku referentnu mjeru poput prihoda, imovine ili uloženog vlasničkog kapitala uz različite inačice izračuna. ${ }^{1} \mathrm{U}$ radu se, kao partikularni izraz profitabilnosti društva, koristiti rentabilnost, odnosno sposobnost ostvarenja profita u odnosu na imovinu (ROA, return on assets) i uloženi vlasnički kapital (ROA, return on equity).

Likvidnost u mikroekonomskom smislu označava sposobnost cirkulacije i pretvaranja manje likvidnih oblika imovine u likvidnije oblike, a u platežnom smislu kao sposobnost društva u podmirenju dospjelih obveza u roku njihova dospijeća. ${ }^{2}$ U praksi se primjenjuje široki dijapazon mjera likvidnosti, statičke i dinamič-

${ }^{1}$ Uže promatrano, obuhvat pojmova profitabilnost i rentabilnost je različit. Profitabilnost označava omjer neke kategorije dobiti u odnosu na kategoriju prihoda, dok rentabilnost označava omjer neke kategorije dobiti i uložene imovine, dobiti i kapitala, odnosno dobiti i ukupno angažiranog kapitala. U anglosaksonskom značenju, profitabilnost je širi pojam od rentabilnosti i pojmovno obuhvaća i rentabilnost. Za svrhu ovog istraživanja, koristi se pojam profitabilnosti u značenju rentabilnosti, odnosno mjere dobiti u odnosu na uloženu imovinu (return on assets, ROA), kao i dobiti u odnosu na uloženi vlastiti kapital (return on equity, ROE).

${ }^{2}$ Obično se u teoriji i praksi terminološki isprepleću pojam likvidnosti i solventnosti pri čemu je ključna njihova razlika s obzirom na vjerojatnost opstanka poduzeća, odnosno s obzirom na dovođenje u pitanje računovodstvenog načela trajnosti (neograničenosti) poslovanja. Likvidnost može biti privremenog i sporadičnog karaktera, dok je nesolventnost obično dužeg, trajnijeg karaktera pri čemu potonje označava platežnu nesposobnost i/ili prezaduženost u bilančnom smislu (preveliki omjer dužničkih u odnosu na vlastite izvore financiranja, odnosno veće obveze u odnosu na imovinu). Kod nesolventnosti opravdano se postavlja pitanje opstanka društva. U pravilu, društvo koje je nesolventno, istovremeno je i nelikvidno. S druge strane, privremeno nelikvidno poduzeće ne mora nužno biti nesolventno u statičkom smislu (dakle, još uvijek može imati veću imovinu od obveza). Dakako da, sukladno gore iznesenom, dugotrajna tj. kronična nelikvidnost u završnoj fazi prelazi u nesolventnost. 
ke mjere, kao i varijacije s korištenjem novčanih kategorija (elemenata novčanog toka) umjesto tradicionalnih računovodstvenih kategorija (Atieh, 2014).

Cilj ovog rada je istražiti postojanje kauzalnost na relaciji rentabilnost - likvidnost na odabranoj skupini društava uvrštenih na Zagrebačkoj burzi. Uvjet za ulazak u spomenuti uzorak je uvrštenost poslovnog subjekta u barem jedan od burzovnih dioničkih indeksa Zagrebačke burze, bilo u agregatnim burzovnim indeksima (CROBEX, CROBEX10) ili u sektorskim indeksima.

Članak obuhvaća pet poglavlja. Nakon uvodnog dijela, u drugom poglavlju izaže se teorijska osnovica veze rentabilnosti i likvidnosti uz sistematizaciju znanstvene i stručne literature. U trećem poglavlju objašnjena je metodološka osnovica istraživanja te način formiranja uzorka. U četvrtom poglavlju analiziraju se $\mathrm{i}$ interpretiraju rezultati, značaj rezultata te se uspoređuju s rezultatima prethodnih istraživanja. U zadnjem poglavlju zaključno se rezimiraju glavne opservacije rada s preporukama za daljnja istraživanja u ovom području.

\section{TEORIJSKA OSNOVICA I REZULTATI PRETHODNIH ISTRAŽIVANJA}

Postoji značajan opus znanstvenih istraživanja u pokušaju utvrđivanja smjera i jačine međusobnog kauzaliteta ili korelacije profitabilnosti (u širem smislu) i likvidnosti. Iako su smjer i jačina kauzaliteta profitabilnosti i likvidnosti, odnosno korelacija već dugo zastupljeni u znanstvenim i stručnim istraživanjima, empirijski rezultati nisu rezultirali jednoznačnim zaključcima. Istraživanja su se uobičajeno usmjeravala na određeno geografsko područje, određenu industriju te na kriterij veličine društava (npr. velika u odnosu na mala i srednja društva). Stupanj i mjera njihove međusobne kauzalnosti u prijašnjim istraživanjima i radovima ipak su značajno ovisili o definicijskim i parametarskim obilježjima ovih kategorija. Veliki dio prethodnih istraživanja značajnu je pažnju usmjerio na jednosmjerne uzročnoposljedične veze profitabilnosti i likvidnosti. Jedna skupina radova je istraživala povezanost tih varijabli pri čemu su se likvidnost, odnosno različiti pokazatelji likvidnosti društva uglavnom držali nezavisnom varijablom, a profitabilnost zavisnom varijablom, dok se u drugoj skupni istraživanja likvidnost promatrala kao zavisna varijabla, a profitabilnost kao nezavisna varijabla. Pregled i sistematizacija teorijske podloge i empirijskih rezultata navode se u nastavku.

Orsag (2011) navodi da je “.... moguće izdvojiti tri područja upotrebe pojma likvidnosti. To su: likvidnost financijskih instrumenata, likvidnost poslovanja i likvidnost imovine poduzeća" (Orsag, 2011, 116). Kada govori o likvidnosti po- 
slovanja onda istu definira kao "...sposobnost odvijanja poslovanja bez zastoja, kroz slobodnu cirkulaciju imovine u poslovnim procesima bez zastoja." (Orsag, 2011, 117). Orsag (2015) u kasnijem radu proširuje definiciju likvidnosti poslovanja na način da likvidnost poslovanja definira kao "sposobnost cirkulacije imovine u poslovnim procesima poduzeća, i to onim volumenom i onom dinamikom koja najbolje usklađuje profitabilnost i rizik, dakle dinamikom koja će se najbolje odraziti na stvaranje vrijednosti za dioničare”. Likvidnost imovine „....određena je kroz unovčivost poslovne imovine kroz redovno odvijanje poslovnih procesa" dok je likvidnost financijskih instrumenata odnosno likvidnost investicijske imovine „sposobnost dionica, obveznica i drugih utrživih vrijednosnih papira da se pretvore u novac po očekivanoj cijeni““ (Orsag, 2011, 2015).

Prema Belaku (2014) likvidnost se može definirati kao sposobnost plaćanja tekućih obveza, a obzirom da se pokazatelji likvidnosti računaju temeljem bilance koja vrijedi na određeni dan, samo neki od njih upućuju na buduće performanse.

Prema Mamić Sečer, Tušek i Korica (2013) uvjet za kontinuirano održavanje likvidnosti je postojanje neto radnog kapitala tj. kada se dio kratkotrajne imovine financira iz dugoročnih izvora.

Richards i Laughlin (1980) ukazuju na prednost mjerenja likvidnosti pokazateljem ciklusa konverzije novca pred tradicionalnim statičkim pokazateljima kao što su tekuća i ubrzana likvidnost. Tradicionalni pokazatelji naglašavaju pristup likvidacije poslovanja i sposobnost da se tekuće kratkoročne obveze podmire likvidacijom kratkoročne imovine, dok zanemaruju načelo kontinuiteta poslovanja (going concern). Prema autorima ciklus konverzije novca jest alat efikasnijeg menadžmenta radnog kapitala upravo u cilju osiguranja potrebnog optimalnog iznosa i optimalnog „timinga“ radnog kapitala.

Kod pokazatelja profitabilnosti mjeri se udio ostvarenog profita u definiranoj referentnoj veličini. Prema Orsagu (2015) dvije su skupine pokazatelja profitabilnosti poduzeća: profitabilnost prodaje i profitabilnost imovine (kapitala). Profitabilnost prodaje mjeri se maržom kontribucije i maržom profita (bruto profitna marža i neto profitna marža), profitabilnost imovine mjeri se pokazateljem ROA, dok se profitabilnost glavnice mjeri pokazateljem ROE.

Helfert (1997) navodi razliku između profitabilnosti imovine i profitabilnosti glavnice. Profitabilnost imovine ima glavni značaj u ocjeni djelotvornosti upravljanja dok je profitabilnost glavnice glavni pokazatelj s gledišta vlasnika.

Belak (2014) govori o zaradi koja predstavlja širi pojam profitabilnosti i definira se kao sposobnost povećanja bogatstva vlasnika poduzeća kroz neto dobit i vrijednost poduzeća, kreditora i investitora kroz kamate i države kroz naplatu poreza na dobit. Dok je profitabilnost u užem smislu povećanje bogatstva poduzeća i njegovih vlasnika. Izdvojene osnovne kategorije dobiti prema ovom autoru jesu: 
poslovni EBIT, EBIT, ponavljajući EBIT, EBITDA, neto dobit i neto dobit uvećana za kamate i umanjena za porez, dok su relativni pokazatelji profitabilnosti ROI, ROE, ROA, ROCE te pokazatelji profitne marže, odnosno neto i bruto profitna marža. Belak navodi i profitabilnost mjerenu novčanim pokazateljima kao što su novčani ROE i novčana profitna marža.

White, Sondhi i Fried (1994) u analizi profitabilnosti razlikuju pokazatelje povrata na prodaju i povrata na ulaganje. U pokazateljima povrata na prodaju navode bruto profitnu maržu, operativnu maržu, maržu prije kamata i poreza, maržu prije poreza, neto profitnu maržu i maržu kontribucije, dok u pokazateljima povrata na ulaganje obrađuju ROA, ROCE i ROE.

Morris i Daley (2009) u svojim modelima razlikuju pokazatelje profitabilnosti (EBITDA/prodaja, EBIT/prodaja, profitna marža prije oporezivanja, neto profitna marža) i pokazatelje povrata na ulaganje (ROA, ROE i ROCE).

Žager i Žager (2008) pokazatelje profitabilnosti dijele na pokazatelje marže profita, pokazatelje rentabilnosti ukupne imovine i pokazatelje rentabilnosti vlastitog kapitala.

Shim i Siegel (2007) ukazuju na tradicionalni odnos između likvidnosti i profitabilnosti. Autori naglašavaju da optimalnim upravljanjem novcem, potraživanjima i zalihama društvo može maksimirati stopu povrata i minimalizirati rizik likvidnosti i poslovanja. Između rizika likvidnosti i povrata postoji odnos reciprociteta, rizik likvidnosti se smanjuje držanjem kratkotrajne imovine u višem iznosu od dugotrajne imovine, a stopa povrata se smanjuje iz razloga što je stopa povrata na kratkotrajnu imovinu niža od stope povrata na dugotrajnu imovinu.

Hirigoyen (1985) govori o odnosu između likvidnosti i profitabilnosti u kratkom odnosno srednjem i dugom roku. Prema ovom autoru odnos likvidnosti i profitabilnosti u srednjem i dugom roku može biti pozitivan odnosno niska likvidnost rezultira niskom profitabilnošću zbog potrebe za dodatnim zaduženjem, a s druge strane niska profitabilnost neće generirati dovoljno novčanog toka.

Istraživanje utjecaja upravljanja radnim kapitalom na performanse kompanije prema Caballero, Garcia-Teruel i Martínez-Solano (2014) ukazuju na dva različita pogleda na ovaj problem. Prema jednom mišljenju viši radni kapital omogućava kompaniji da poveća prodaju i ostvari veći diskont na ranije plaćanje obveza čime može povećati vrijednost kompanije, dok prema drugom mišljenju viši radni kapital stvara potrebu za dodatnim financiranjem čime se povećavaju troškovi financiranja i smanjuje profitabilnost, a posljedično i vrijednost kompanije.

Cristea i Cristea (2016) zaključuju da neadekvatna likvidnost može dovesti do likvidacije kompanije dok pretjerana likvidnost može negativno utjecati na profitabilnost kompanije. 
Prema Wolski i Bolek (2016) generalna formulacija tradicionalne teorije koja zaključuje da se rastom likvidnosti profitabilnost smanjuje, nema smisla i odnosi se samo na definiranju odnosa između statičkih pokazatelja likvidnosti i profitabilnosti. Prema istim autorima neuzimanje u obzir troškova vlasničke glavnice odnosno utjecaja tržišta kapitala prilikom mjerenja profitabilnosti rezultira neadekvatnim zaključcima istraživanja.

U istraživanja se ponekad uključuju i tzv. pomoćne nezavisne varijable, kao što su: veličina kompanije, starost kompanije, stopa rasta, udio dugotrajne imovine u ukupnoj imovini, stupanj financijske poluge, tržišna snaga kompanije (Korent i Orsag, 2018); veličina kompanije, pokazatelj zaduženja, ponder dugotrajne imovine u ukupnoj imovini (Gill, Biger i Mathur, 2010) te rast prodaje, stopa zaduženja, ponder dugotrajne imovine u ukupnoj imovini i varijabilnost neto operativnog dobitka (Deloof, 2003).

Kao mjerilo likvidnosti koriste se različiti pokazatelji, najveći dio autora koristi statičke pokazatelje likvidnosti (trenutna, tekuća, ubrzana likvidnost i koeficijent stabilnosti), dok manji dio istraživanja koristi dinamičke pokazatelje odnosno pokazatelje neto radnog kapitala (udio neto radnog kapitala i ukupnih prihoda, novčani jaz odnosno ciklus konverzije novca). Međutim, nužno je naglasiti da recentnija istraživanja više uključuju neke od dinamičkih mjera likvidnosti. Kod mjerenja profitabilnosti najčešce se koriste pokazatelji ROA i ROE, pokazatelj ROCA, neto dobitak, bruto operativni dobitak, a nešto rjeđe EBITDA, $\mathrm{ROE}_{\text {kapital i rezerve }}$, ROT, profitna marža.

U istraživanjima koja likvidnost mjere statičkim pokazateljima nalazi se i najveći broj hrvatskih autora. Rezultati ovih istraživanja su, u najvećem dijelu istraživanja, dvojaki:

- Istraživanje utvrđuje pozitivnu vezu između pokazatelja likvidnosti i profitabilnosti (Sorić, 2002; Serdarušić, 2007; Mamić Sečer, Tušek i Korica, 2013; Gabrić, 2015; Amhad, 2016; Korent i Orsag, 2018)

- Istraživanje utvrđuje negativnu vezu između pokazatelja likvidnosti i profitabilnosti (Stjepanović i Cita, 2016; Svitlík and Poutník, 2016; Raykov, 2017)

Sorić (2002) analizira povezanost između poslovnog rezultata i likvidnosti na uzroku poduzeća iz Splitsko-Dalmatinske županije u razdoblju od 1996. do 2000. godine. Uzorak čini cjelokupno gospodarstvo Splitsko-Dalmatinske županije. Analizom je utvrđeno da postoji korelacijska veza između niskih stopa likvidnosti i iskazanog neto gubitka koji je u analiziranom razdoblju karakterizirao poslovanje gospodarskih subjekata iz promatranog uzorka. Naime, utvrđeno je da porast gubitka prati istovremeni pad likvidnosti poslovanja. 
Serdarušić (2007) istražuje utjecaj financijskog položaja i aktivnosti na novčani jaz i profitabilnost hrvatskog turističkog sektora u razdoblju od 2001. do 2004. godine (uzorak od ukupno 36 poduzeća). Novčani jaz mjeri kao razliku sume dana vezivanja zaliha i dana vezivanja potraživanja umanjene za dane vezivanja obveza prema dobavljačima. Između ostalih odnosa autor utvrđuje i korelaciju između statičkih pokazatelja likvidnosti i pokazatelja profitabilnosti. Profitabilnost mjeri pokazateljima EBITDA, $\mathrm{ROE}_{\text {ukupno }}, \mathrm{ROE}_{\text {kapital i rezerve }}, \mathrm{ROT}$ i ROA. Na analiziranom uzorku autor ukazuje na srednje jaku pozitivnu korelaciju između pokazatelja likvidnosti (trenutna likvidnost, ubrzana likvidnost, tekuća likvidnost i radni kapital) i profitabilnosti u promatranom vremenskom razdoblju. Autor je $\mathrm{u}$ radu analizirao i korelaciju novčanog jaza i pokazatelja profitabilnosti te zaključuje da je rezultat utjecaja novčanog jaza na profitabilnost dugoročno slab, a kratkoročno može utjecati u određenoj mjeri.

Mamić Sečer, Tušek i Korica (2013) analizirali su utjecaj likvidnost na profitabilnost srednje velikih i velikih poduzeća u grani djelatnosti Informacije i komunikacije (uzorak od 44 poduzeća koja su 2009. godine poslovala u Republici Hrvatskoj) za razdoblje od 2007. do 2009. godine. Analizom je utvrđeno da povećanje vrijednosti koeficijenta tekuće likvidnosti utječe na povećanje koeficijenta bruto rentabilnosti imovine.

Gabrić (2015) ispituje povezanost između profitabilnosti i likvidnosti na uzorku poduzeća uvrštenih na kotaciju i primarno tržište na Sarajevskoj burzi u razdoblju od 2010. do 2013. godine. Uzorak uključuje 19 poduzeća. Likvidnost autor mjeri pokazateljima trenutne likvidnosti, ubrzane likvidnosti, tekuće likvidnosti i financijske stabilnosti dok profitabilnost mjeri pokazateljima neto profitne marže, bruto profitne marže, neto rentabilnošću imovine, bruto rentabilnošću imovine i rentabilnošću kapitala. Rezultati istraživanja ukazali su da postoji pozitivna korelacija između pokazatelja profitabilnosti i pokazatelja likvidnosti kod poduzeća iz promatranog uzorka.

Amhad (2016) istražuje međuovisnost likvidnosti i profitabilnosti na primjeru Standard Chatered Bank Pakistan u razdoblju od 2004. do 2013. godine. Kao mjerilo likvidnosti korišteni su pokazatelji tekuće likvidnosti, ubrzane likvidnosti i neto radni kapital, a kao mjerilo profitabilnosti korišteni su pokazatelji bruto dobitka, neto dobitka, ROA i ROE. Rezultati ukazuju na slabu pozitivnu vezu između pokazatelja likvidnosti i profitabilnosti.

Korent i Orsag (2018) vrednovali su utjecaj menadžmenta radnog kapitala na profitabilnost hrvatskih kompanija iz djelatnosti Računalno programiranje, savjetovanje i djelatnosti povezane s njima. Uzorak se sastojao od 442 kompanije čiji su se podaci analizirali za razdoblje od 2008. do 2013. godine. Profitabilnost je mjerena pokazateljem ROA dok je likvidnost mjerena neto radnim kapitalom (udio neto radnog kapitala u ukupnim prihodima). Analizom je utvrđeno da model u kojem 
su uz glavnu nezavisnu varijablu (neto radni kapital) korištene i pomoćne nezavisne varijable (veličina kompanije, starost kompanije, stopa rasta, udio dugotrajne imovine u ukupnoj imovini, stupanj financijske poluge, tržišna snaga kompanije) ukazuje na zaključak da upravljanje radnim kapitalom značajno utječe na profitabilnost kompanija. Nadalje, ukazuje se na postojanje nelinearne konkavne kvadratne veze između radnog kapitala i povrata na imovinu. Analiza sugerira postojanje optimalne razine radnog kapitala uz koju se maksimizira profitabilnost poslovanja.

Stjepanović i Cita (2016) analiziraju međuovisnost poslovnog rezultata i pokazatelja likvidnosti hrvatskih poduzeća iz prehrambene djelatnosti za razdoblje od 2011. do 2015. godine. Uzorak čini 31 poduzeće iz prehrambene djelatnosti. Uspješnost poslovanja mjeri se visinom ostvarene neto dobiti koja predstavlja mjeru profitabilnost dok se likvidnost mjeri pokazateljima trenutne, tekuće i ubrzane likvidnosti. Istraživanje je pokazalo značajnu negativnu povezanost ostvarene neto dobiti i pokazatelja tekuće i ubrzane likvidnosti dok je korelacija između neto dobiti i trenutne likvidnosti nisko pozitivna.

Svitlík and Poutník (2016) u svom istraživanju utvrđuju vezu između nekoliko pokazatelja likvidnosti te između pokazatelja likvidnosti i profitabilnosti u Češkoj Republici, na uzorku od 241.128 kompanija za razdoblje od 10 godina (od 2003. do 2013. godine). Istraživanjem su utvrdili da postoji statistički signifikantna korelacija između pokazatelja likvidnosti (tekuće i ubrzane likvidnosti) dok je niža korelacija evidentirana između statičkih pokazatelja likvidnosti i obrtaja neto radnog kapitala (neto radni kapital / ukupan promet). Istovremeno utvrđuju statistički značajnu korelaciju samo između pokazatelja obrtaja radnog kapitala i pokazatelja ROA osim za godine 2007., 2008. i 2011. za koje nije utvrđena korelacija. Između statičkih pokazatelja likvidnosti i ROA pokazatelja nije utvrđena korelacija.

Raykov (2017) istražuje međuovisnost likvidnosti i profitabilnost na uzorku od 20 kompanija koje su sastavnice dioničkog indeksa BGBX40 Bugarske burze u razdoblju od 2007. do 2015. godine. Likvidnost mjeri pokazateljem ubrzane likvidnost, a profitabilnost pokazateljem ROCA. Analizom je utvrđena negativna korelacija između likvidnosti i profitabilnosti, a istovremeno je zaključeno da smjer utjecaja ide s pokazatelja likvidnosti na pokazatelj profitabilnosti, ali ne i u obrnutom smjeru.

U istraživanjima gdje je likvidnost mjerena ciklusom konverzije novca može se pronaći četiri grupe zaključaka:

I. Skraćivanje ciklusa konverzije novca utječe na povećanje profitabilnosti u poslovanju, odnosno utvrđena je negativna korelacije između dviju veličina. Skraćivanje ciklusa konverzije novca moguće je skraćivanjem dana vezivanja potraživanja i zaliha te povećanjem dana vezivanja dobavljača (Shin i Soenen, 1998; Eljelly, 2004; Baidh, 2013; Cristea and Cristea, 2016) 
II. Skraćivanje dana vezivanja potraživanja i dana vezivanja zaliha povećava profitabilnost te je utvrđena negativna veza između ovih komponenti ciklusa konverzije novca i profitabilnosti dok povećanje dana vezivanja obveza prema dobavljačima utječe na smanjenje profitabilnost, čime je utvrđena negativna korelacije i između ove komponente i profitabilnosti poslovanja (Deloof, 2003; Lazaridis i Tryfonidis, 2006; Falope i Ajilore, 2009)

III. Pozitivna korelacija između ciklusa konverzije novca i profitabilnosti (Gill, Biger i Mathur, 2010)

IV. Nepostojanje statistički značajne veze između ciklusa konverzije novca i profitabilnosti (Serdarušić, 2007; Tušek, Perčević, Hladika, 2014)

Shin i Soenen (1998) analizirali su vezu između efikasnosti menadžmenta radnog kapitala i profitabilnosti kompanije na uzorku od 58.985 američkih kompanija iz Compustat baze. Analiziran je uzorak za razdoblje od 20 godina, odnosno od 1975. do 1994. godine. Kao mjerilo efikasnosti menadžmenta radnog kapitala korišten je pokazatelj neto poslovnog ciklusa (engl. Net Trade Cycle, NTC) odnosno ciklus konverzije novca, a mjerilo profitabilnosti jest operativni dobitak uvećan za amortizaciju podijeljen s ukupnom imovinom odnosno operativni dobitak uvećan za amortizaciju podijeljen s neto prodajom. Analizom je utvrđena snažna negativna veza između pokazatelja NTC i profitabilnosti, odnosno kompanije s kraćim razdobljem neto poslovnog ciklusa iskazuju veću profitabilnost. Profitabilnost je značajno negativno korelirana i s pokazateljem tekuće likvidnosti.

Eljelly (2004) na uzorku 29 kompanija u Saudijskoj Arabiji u razdoblju od 1996. do 2000. godine analizira odnos između profitabilnosti i likvidnosti. Likvidnost se mjeri pokazateljima tekuće likvidnosti i ciklusom konverzije novca, dok se profitabilnost mjeri visinom neto operativnog dobitka. Iz istraživanja proizlazi zaključak o negativnom odnosu između profitabilnosti i likvidnosti, mjerene pokazateljem tekuće likvidnosti te o negativnom odnosu profitabilnosti i likvidnosti mjerene ciklusom konverzije novca. Istraživanje je pokazalo da pokazatelj tekuće likvidnosti ima veći utjecaj na profitabilnost od pokazatelja ciklusa konverzije novca, uz izuzetak proizvođačke djelatnosti, u kojoj ciklus konverzije novca kao pokazatelj likvidnosti ima veći utjecaj na profitabilnost od pokazatelja tekuće likvidnosti.

Cristea i Cristea (2016) analiziraju odnos između menadžmenta radnog kapitala i profitabilnosti kompanije na uzorku proizvodnih kompanija izlistanih na Bukureštanskoj burzi (Bucharest Stock Exchange) za razdoblje od 2011. d 2015. godine. Rezultati istraživanja ukazuju na negativnu korelaciju između ciklusa konverzije novca i pokazatelja ROA, odnosno profitabilnost kompanije raste kako se smanjuje ciklus konverzije novca. Isto znači da kompanija može povećati profita- 
bilnost smanjenjem dana vezivanja zaliha i dana vezivanja potraživanja te povećanjem dana vezivanja obveza prema dobavljačima.

Baidh (2013) istražuje odnos između menadžmenta radnog kapitala i profitabilnosti na uzorku kompanija izlistanih na Indijskoj burzi u razdoblju od pet godina. Rezultati istraživanja ukazuju na negativnu korelaciju između dana vezivanja potraživanja i profitabilnosti te pozitivnu korelaciju između dana vezivanja dobavljača i profitabilnosti.

Deloof (2003) istražuje odnos između menadžmenta radnog kapitala i profitabilnosti na uzorku od 1.009 belgijskih nefinancijskih kompanija u razdoblju od 1992. do 1996. godine. Ciklus konverzije novca koristi se kao mjera menadžmenta radnoga kapitala, dok se profitabilnost mjeri stopom bruto operativnog dobitka. Istraživanjem je utvrđena negativna veza između bruto operativnog dobitka i dana vezivanja potraživanja, zaliha i dobavljača, odnosno što je duži broj dana vezivanja potraživanja profitabilnost je niža, što je duže razdoblje vezivanja zaliha profitabilnost je niža te što je duže razdoblje naplate potraživanja profitabilnost je niža.

Lazaridis i Tryfonidis (2006) utvrđuju odnos između menadžmenta radnog kapitala i profitabilnosti na uzorku 131 grčke kompanije izlistane na "Athens Stock Exchange”. Analiza je izvršena za razdoblje od 2001. do 2004. godine. Kao mjerilo uspješnosti menadžmenta radnog kapitala korišten je pokazatelj ciklusa konverzije novca sa svim svojim pojedinačnim komponentama (dani vezivanja zaliha, dani vezivanja potraživanja i dani vezivanja obveza prema dobavljačima), dok je kao mjerilo profitabilnosti korišten pokazatelj bruto operativne dobiti. Rezultati istraživanja ukazali su na negativnu vezu između pokazatelja profitabilnosti i ciklusa konverzije novca, odnosno skraćenje ciklusa konverzije novca utječe na povećanje profitabilnosti kompanije. Negativna veza utvrđena je i između dana vezivanja potraživanja, dana vezivanja dobavljača i dana vezivanja zaliha i profitabilnosti. Autori zaključuju sljedeće, što je duže razdoblje plaćanja obveza prema dobavljačima niža je profitabilnost jer u pravilu manje profitabilne kompanije plaćaju svoje obveze kasnije, s druge strane povećanje dana vezivanja potraživanja i dana vezivanja zaliha vezano je uz ostvarenje niže profitabilnosti.

Isti rezultati istraživanja evidentni su i kod Falope i Ajilore (2009) koji na uzorku od 50 kompanija uvrštenih na Nigerian Stock Exchange, analizom financijskih izvještaja za razdoblje od 1996. do 2005. godine utvrđuju negativnu vezu između profitabilnosti s jedne strane i ciklusa konverzije novca, dana vezivanja zaliha, dobavljača i potraživanja s druge strane.

Gill, Biger i Mathur (2010) analizirali su odnos između menadžmenta radnog kapitala i profitabilnosti na uzorku od 88 američkih kompanija iz proizvođačke djelatnosti u razdoblju od 2005. do 2007. godine. Kao mjera likvidnosti odnosno uspješnosti upravljanja radnim kapitalom uzet je podatak o ciklusu konverzije 
novca dok je kao mjerilo profitabilnosti korišten bruto operativni dobitak. Autori su analizom utvrdili negativan odnos (korelaciju) između prosječnog broja dana vezivanja potraživanja i profitabilnosti, nadalje utvrdili su da nema statistički signifikantne korelacije između dana vezivanja dobavljača i profitabilnosti te dana vezivanja zaliha i profitabilnosti. Istraživanjem su utvrdili pozitivnu korelaciju između ciklusa konverzije novca i profitabilnosti.

Tušek, Perčević, Hladika (2014) istražuju međuovisnost novčanog jaza kao mjere likvidnosti i profitabilnosti hotelske industrije u Republici Hrvatskoj u razdoblju od 2009. do 2012. godine (uzorak od ukupno 72 poduzeća). Novčani jaz definiraju kao razliku između broja dana prodaje zaliha i naplate potraživanja s jedne strane te broja dana plaćanja obveza dobavljačima s druge strane. Profitabilnost hotelske industrije mjeri se putem tri kategorije: računovodstveno utvrđene dobiti prije oporezivanja, rentabilnosti imovine i rentabilnosti kapitala. Istraživanjem su zaključili da ne postoji statistički značajna linearna veza između novčanog jaza i računovodstvene dobiti prije oporezivanja s jedne strane, odnosno rentabilnosti imovine s druge strane te rentabilnosti kapitala s treće strane.

Wolski i Bolek (2016) analiziraju odnos likvidnosti profitabilnosti na uzorku 395 kompanija, izlistanih na Warsaw Stock Exchange, u razdoblju od 1997. do 2012. godine. Mišljenje je autora da statičke mjere likvidnosti i profitabilnosti nisu dobro mjerilo za istraživanje odnosa između ovih pokazatelja poslovanja, isto tako naglašavaju da istraživanje u kojem se utvrđuje odnos između npr. statičkih pokazatelja profitabilnosti (ROA, ROE) i dinamičkog pokazatelja likvidnosti (ciklus konverzije novca) isto predstavlja metodološki problem u interpretaciji zaključaka istraživanja. Iz navedenih razloga autori istražuju odnos između dinamičkog pokazatelja likvidnosti (ciklus konverzije novca) i dinamičkog pokazatelja profitabilnosti (pokazatelj $\mathrm{EVA}^{3}$ ) te zaključuju da je korelacija između ova dva pokazatelja negativna, odnosno profitabilnost se smanjuje povećanjem ciklusa konverzije novca.

\section{METODOLOGIJA I SPECIFIKACIJA MODELA}

Postavljanje modela i metodologije prethodno zahtijeva teorijsku elaboraciju interakcije rentabilnosti i likvidnosti i očekivanja koja proizlaze iz takve interakcije. Ta veza je, prema mišljenju autora, svakako dvosmjerna, odnosno niti jedna od navedenih varijabli ne može se promatrati nezavisno u odnosu na drugu varijablu. Odgovarajuća likvidnost je preduvjet za dugoročnu rentabilnost društva. Naime,

3 Pokazatelj EVA izračunat je bez računovodstvenih prilagodbi 
ako društvo nema dovoljno likvidne imovine i/ili nije u stanju uredno podmirivati dospjele obveze, pojavljuju se oportunitetni troškovi u vidu gubitka prihoda (npr. nedovoljne zalihe proizvoda za isporuku ili restriktivna politika naplate), zastoji u nabavi inputa (i odnosima s dobavljačima), pad produktivnosti (radi kašnjenja i/ili neisplate plaća), neredovne i zakašnjele isporuke kupcima, obračun zateznih kamata, blokade poslovnog računa i sl., koje na izravan ili neizravan način ugrožavaju i/ili ograničavaju rentabilnost. Niti jedno društvo koje je nelikvidno ne može ostvariti optimalni profitni potencijal. S druge strane, prevelika likvidnost i zastupljenost likvidne imovine, iako poželjna s aspekta platežne sposobnosti, također nije poželjna s aspekta oportunitetnih troškova i troškova kapitala, jer ograničava potencijal postizanja više rentabilnosti. Naime, višak likvidne imovine koja nije u neposrednoj funkciji poslovnih operacija, odnosno neangažirana likvidna imovina (poput neoperativnog novca, dakle novca koji nije u funkciji poslovanja) je trošak s dva gledišta. S prvog gledišta, takva imovina nema odgovarajuće prinose, odnosno moguće je investabilna u druge profitabilnije svrhe. Također, takva imovina financirana je cjenovno skupim vlasničkim i/ili dužničkim kapitalom koji nadilazi prinose po takvoj imovini. Tehnički analizirano - kroz financijske pokazatelje, neangažirana (likvidna ili manje likvidna) imovina se manifestira u nižem koeficijentu obrtaja ukupne imovine i stoga, uz uvjet ceteris paribus, utječe na manju rentabilnost ukupne imovine (return on assets, ROA), odnosno uloženog kapitala kojim je financirana ta imovina.

Uz uvjet odsustva vanjskih akcija (poput dodatnih eksternih ulaganja kojima se nadoknađuje deficit likvidnosti), određeni stupanj rentabilnosti je nužan za očuvanje dugoročne likvidnosti. Kolika je visina rentabilnosti neophodna za očuvanje likvidnosti obično je određeno stupnjem uspjeha transformacije prihoda u novac, kao i stupnjem uspješnosti u pokriću troška (vlasničkog i dužničkog) kapitala postojećim poslovnim operacijama. Vodeći se osnovnim financijskim relacijama ${ }^{4}$, interes menadžmenta je pronaći optimalnu ili dovoljnu razinu likvidnosti koja će s jedne strane osigurati kontinuitet i protočnost poslovnih operacija, a s druge strane neće ograničavati ili ugrožavati potencijal više rentabilnosti.

Temeljem prethodne elaboracije postavljaju se sljedeće hipoteze istraživanja.

\section{Hipoteze}

Nulta hipoteza $H_{0}-$ Ne postoji signifikantna međusobna uzročnost varijabli rentabilnosti (ROE i ROA) $i$ varijabli likvidnosti (koeficijent tekuće likvidnosti $i$ koeficijent ubrzane likvidnosti).

${ }^{4}$ Npr. dekompozicija prinosa na vlastiti kapital (ROE) kroz maržu neto dobiti, koeficijent obrtaja ukupne imovine i financijsku polugu, u praksi poznate pod nazivom DuPont-ova analiza. 
Alternativna hipoteza $H_{1}$ - Prisutna je signifikantna uzročnost varijabli rentabilnosti (ROE $i$ ROA) na varijable likvidnosti (koeficijent tekuće likvidnosti $i$ koeficijent ubrzane likvidnosti) $i$ prisutna je signifikantna uzročnost varijabli likvidnosti (koeficijent tekuće likvidnosti i koeficijent ubrzane likvidnost) na varijable rentabilnosti (ROE i ROA).

Uvjet za uvrštenje društva u uzorak istraživanja je prisutnost društva u barem jednom od agregatnih ili sektorskih dioničkih indeksa Zagrebačke burze. Navedeni kriterij je ispunilo ukupno dvadeset društava što predstavlja i uzorak za istraživanje. Ovaj uzorak je odabran jer predstavljaju kompanije najizloženije financijskoj transparentnosti i pokrivenosti praćenja od strane profesionalnih analitičara i investicijske javnosti. Drugi razlog je što takva društva obično imaju profesionalni visoko-stručni financijski menadžment kao funkciju i kao proces i koji naročitu pažnju vode o optimalnom odnosu rentabilnosti i likvidnosti.

Vremensko razdoblje obuhvaća devet godina, počevši od 2009. godine do zaključno s obuhvatom 2017. godine.

Prikupljeni podatci obuhvaćaju nekoliko varijabli profitabilnosti i likvidnosti.

Promatrane varijable rentabilnosti su:

- prinos na uloženu imovinu (ROA), mjeren odnosom operativne dobiti prije kamata i amortizacije (EBIT) i ukupne imovine,

- prinos na uloženi kapital (ROE), mjeren odnosom neto dobiti i ukupnog vlasničkog kapitala;

Promatrane varijable likvidnosti su:

- koeficijent tekuće likvidnosti (omjer kratkotrajne imovine i kratkoročnih obveza ),

- koeficijent ubrzane likvidnosti (omjer kratkotrajne imovine umanjene za zalihe i kratkoročnih obveza),

Svi ulazni podatci su dobiveni iz javno objavljenih povijesnih financijskih izvještaja kompanija iz uzorka s poviješću od devet godina. ${ }^{5}$ Podatci iz računa dobiti i gubitka i izvještaja o novčanim tokovima su na godišnjoj razini, dok su podatci iz bilance na kraju promatranog razdoblja (promatrane godine).

S obzirom da varijable sadrže vremensku i prostornu komponentu, a za svaku jedinicu promatranja u svakom razdoblju potrebni podaci su dostupni, varijable su strukturirane kao balansirani panel podaci, što ukupno čini 180 opservaciju za svaku varijablu (20 panela po 9 promatranja). Sukladno ciljevima istraživanja

${ }^{5}$ Izvor financijskih izvještaja je informacijsko-financijska baze Screener.co (dostupne uz pretplatu na: https://stock.screener.co). Ulazni podatci su iz baze Thomson Reuters. 
koji se temelje na ispitivanju uzročnosti između odabranih varijabli, te s obzirom na formulaciju dostupnih podataka u panel oblik, podaci su obrađeni primjenom metodologije koja odgovara ciljevima istraživanja, te koja je prilagođena panel formulaciji podataka.

U cilju utvrđivanja međusobne uzročnosti između promatranih varijabli, $u$ radu je proveden Grangerov test uzročnosti prilagođen panel formulaciji podataka (Granger, 1969) i (Dumitrescu i Hurlin, 2012). Također, u radu se provodi model panel vektorske autoregresije - PVAR (Sigmund i Ferstl, 2017). U sklopu PVAR metodologije obrađena je analiza strukture modela: ortogonalna dekompozicija varijanci prognostičkih pogrešaka (engl. Forecast Error Variance Decomposition - FEVD) i analiza ortogonalne funkcije impulsnih odziva (eng. Orthogonal Impulse Response Function - OIRF), sukladno metodologijama (Lutkepohl, 2007) i (Pfaff, 2008) koje su autori Sigmund i Ferstl (2017) pratili u svom radu.

Procjena parametara u PVAR modelu je provedena primjenom generalizirane metode momenata - GMM (engl. Generalized Method of Moments), gdje je neopaženi individualni (fiksni) panel efekt uklonjen ortogonalnom transformacijom - FOD (engl. forward orthogonal transformation). Za odabir broja lagiranih varijabli u PVAR modelu je korišten kriterij prema Andrews i Lu (2001). Također, da bi se utvrdila stabilnost pokrenutih regresijskih jednadžbi, u modelu je korišten karakteristični polinom matrice i prezentirane su vrijednosti modula svojstvene vrijednosti. Prije pokretanja PVAR modela, proveden je formalni test jediničnog korijena za sve varijable baziran na proširenom Dickey-Fuller testu (Dickey i Fuller, 1979), prilagođenom panel formulaciji (Levin, Lin i Chu, 2002), s kojim će se ispitati stacionarnost varijabli. Oznaka za varijablu koeficijent ubrzane likvidnosti je QR (quick ratio), a za varijablu koeficijent tekuće likvidnosti CR (curent ratio). Varijable ROA i ROE zadržavaju svoje oznake. Za analizu podataka je korišten statistički program , $\mathrm{R}^{“ 6}$.

\section{ANALIZA I INTERPRETACIJA REZULTATA}

Prije interpretacije rezultata testa uzročnosti, odnosno formalnog PVAR modela, nastavku se ukratko prezentiraju rezultati testova koji su utjecali na početnu formulaciju modela. Tablica 1. prikazuje rezultate Levin-Lin-Chu testa jediničnog korijena. Postavljena nulta hipoteza testa ukazuje da serija podataka sadrži jedinični korijen, dok je alternativna hipoteza da je serija stacionarna. Uz mogućnost pogreške od 5\%, nulta hipoteza se odbacuje, odnosno sve varijable su stacionarne u razinama, odnosno u svom izvornom obliku. 
Tablica 1 .

\section{REZULTATI TESTA JEDINIČNOG KORIJENA LEVIN-LIN-CHU (UKLJUČENA KONSTANTA I TREND)}

\begin{tabular}{|c|c|c|c|}
\hline Varijabla & $\begin{array}{c}\text { Broj pomaka } \\
(\text { lagova })\end{array}$ & Testna vrijednost & $\boldsymbol{p}$-Vrijednost \\
\hline$C R$ & 0 & -3.86 & 0,00 \\
\hline$Q R$ & 1 & $-1,97$ & 0,03 \\
\hline$R O A$ & 0 & $-8,84$ & 0,00 \\
\hline$R O E$ & 0 & -13.36 & 0,00 \\
\hline
\end{tabular}

Optimalni broj pomaka u modelu je određen prema Akaike "AIC" informacijskom kriteriju s maksimalnim brojem od 10 .

Izvor: Izrada autora

S obzirom na rezultate jediničnog korijena, analiza se nastavlja na varijablama izraženim u svom izvornom obliku te se pokreće PVAR model. Također, sukladno kriteriju Andrews i Lu (2001) odabran je model panel vektorske autoregresije prvog reda - jednim pomakom (lagiranom varijablom), u odnosu na modele s dva ili tri pomaka, što je prikazano u Tablici 2.

Tablica 2.

\section{KRITERIJI ODABIRA BROJA POMAKA}

\begin{tabular}{|c|c|c|c|}
\hline $\begin{array}{c}\text { Broj pomaka } \\
(\text { lagova })\end{array}$ & BIC & AIC & HQIC \\
\hline 1 & $-2.179,09$ & $-873,00$ & -1.474 .69 \\
\hline 2 & $-2.021,75$ & $-839,86$ & $-1.386,23$ \\
\hline 3 & $-1.780,45$ & $-769,645$ & $-1.237,99$ \\
\hline
\end{tabular}

Izvor: Izrada autora

Tablica 3. prikazuje module svojstvene vrijednosti za pokrenute regresijske jednadžbe u modelu. Ukoliko rješenje jediničnog korijena nema vrijednost , onda su neke ili sve varijable u PVAR modelu integrirane reda I(1), što znači da bi između njih mogla postojati kointegracija. Sve vrijednosti modula svojstvene vrijednosti su manje od jedan, pa se zaključuje da je PVAR model stabilan. 
Tablica 3.

REZULTATI STABILNOSTI PVAR MODELA ZA ČETIRI JEDNADŽBE

\begin{tabular}{|l|l|l|l|l|} 
Moduli svojstvene vrijednosti & 0,5965 & 0,5965 & 0,3009 & 0,3009 \\
\hline
\end{tabular}

Izvor: Izrada autora

Sukladno postavljenoj hipotezi rada o postojanju značajne statističke veze između indikatora likvidnosti i profitabilnosti, u nastavku se provodi Grangerov test uzročnosti prilagođen panel formulaciji podataka. Uzročnost se opisuje kao mogućnost predviđanja reakcije jedne varijable na temelju odnosa s dinamikom neke druge varijable. Prema tome, u radu se ispituje koliko promjene vrijednosti određene uzročne varijable može utjecati na promjenu vrijednosti druge odzivne varijable. Rezultati testa uzročnosti prikazani su u Tablici 4.

Tablica 4.

\section{REZULTATI PANEL GRANGEROVOG TESTA UZROČNOSTI DUMITRESCU - HURLIN}

\begin{tabular}{|c|c|c|}
\hline Uzročna varijabla & Odzivna varijabla & $\boldsymbol{p}$-Vrijednost \\
\hline CR & ROA & 0,26 \\
\hline CR & ROE & 0,20 \\
\hline CR & QR & 0,00 \\
\hline QR & ROA & 0,00 \\
\hline QR & ROE & 0,03 \\
\hline QR & CR & 0,00 \\
\hline ROA & CR & 0,00 \\
\hline ROA & ROE & 0,00 \\
\hline ROA & QR & 0,00 \\
\hline ROE & CR & 0,00 \\
\hline ROE & QR & 0,00 \\
\hline ROE & ROA & 0,00 \\
\hline
\end{tabular}

Izvor: Izrada autora 
Prema Grangerovom testu uzročnosti za dani interval statističke značajnosti od 5\%, rezultati testa ukazuju na visoku uzročnost između promatranih varijabli. Podatci pokazuju značajni međusobni kauzalitet promatranih varijabli osim utjecaja koeficijenta tekuće likvidnosti (kao uzročne varijable) na prinos na ukupnu imovinu i prinos na vlastiti kapital (kao odzivne varijable). Rentabilitet društava promatran kroz prinos na ukupnu imovinu i prinos na vlastiti kapital je značajno utjecao na koeficijente tekuće i ubrzane likvidnosti. S druge strane, veća likvidnost društva mjerena koeficijentom tekuće likvidnosti ne pokazuje značajnu uzročnost na rentabilnost.

Sukladno dobivenim rezultatima, analiza se nastavlja dekompozicijom varijance prognostičkih pogrešaka. Dekompozicijom varijance moguće je utvrditi koliko je varijacija jedne promatrane varijable opisano varijacijama te iste varijable ali i varijacijama drugih varijabli u modelu.

Projekcija ortogonalne dekompozicije varijance za sve četiri varijable je prikazana u Tablici 5. Rezultati se interpretiraju sukladno teoretskoj pretpostavci povezanosti između indikatora likvidnosti i profitabilnosti. 
Tablica 5.

PROJEKCIJA ORTOGONALNE DEKOMPOZICIJE VARIJANCE

\begin{tabular}{|c|c|c|c|c|c|}
\hline $\begin{array}{c}\text { Odzivna } \\
\text { varijabla }\end{array}$ & Broj koraka & CR & QR & ROA & ROE \\
\hline \multirow[t]{8}{*}{ CR } & 1 & 1,00 & 0,00 & 0,00 & 0,00 \\
\hline & 2 & 0,69 & 0,18 & 0,07 & 0,06 \\
\hline & 3 & 0,56 & 0,21 & 0,06 & 0,17 \\
\hline & 4 & 0,52 & 0,20 & 0,05 & 0,23 \\
\hline & 5 & 0,51 & 0,19 & 0,05 & 0,24 \\
\hline & 6 & 0,51 & 0,19 & 0,05 & 0,24 \\
\hline & 7 & 0,51 & 0,19 & 0,05 & 0,24 \\
\hline & 8 & 0,51 & 0,19 & 0,05 & 0,24 \\
\hline \multirow{8}{*}{$\overline{Q R}$} & 1 & 0,73 & 0,27 & 0,00 & 0,00 \\
\hline & 2 & 0,53 & 0,42 & 0,03 & 0,03 \\
\hline & 3 & 0,41 & 0,39 & 0,02 & 0,18 \\
\hline & 4 & 0,37 & 0,36 & 0,02 & 0,25 \\
\hline & 5 & 0,36 & 0,35 & 0,02 & 0,27 \\
\hline & 6 & 0,36 & 0,34 & 0,02 & 0,27 \\
\hline & 7 & 0,36 & 0,34 & 0,02 & 0,27 \\
\hline & 8 & 0,36 & 0,34 & 0,02 & 0,27 \\
\hline \multirow[t]{8}{*}{ ROA } & 1 & 0,13 & 0,71 & 0,16 & 0,00 \\
\hline & 2 & 0,09 & 0,34 & 0,08 & 0,49 \\
\hline & 3 & 0,09 & 0,33 & 0,08 & 0,50 \\
\hline & 4 & 0,10 & 0,33 & 0,08 & 0,50 \\
\hline & 5 & 0,10 & 0,33 & 0,08 & 0,50 \\
\hline & 6 & 0,10 & 0,33 & 0,08 & 0,50 \\
\hline & 7 & 0,10 & 0,33 & 0,08 & 0,50 \\
\hline & 8 & 0,10 & 0,33 & 0,08 & 0,50 \\
\hline \multirow{8}{*}{ ROE } & 1 & 0,00 & 0,03 & 0,03 & 0,94 \\
\hline & 2 & 0,00 & 0,04 & 0,03 & 0,93 \\
\hline & 3 & 0,01 & 0,04 & 0,03 & 0,93 \\
\hline & 4 & 0,01 & 0,04 & 0,03 & 0,93 \\
\hline & 5 & 0,01 & 0,04 & 0,03 & 0,93 \\
\hline & 6 & 0,01 & 0,04 & 0,03 & 0,92 \\
\hline & 7 & 0,01 & 0,04 & 0,03 & 0,92 \\
\hline & 8 & 0,01 & 0,04 & 0,03 & 0,92 \\
\hline
\end{tabular}

Izvor: Izrada autora 
Za varijablu tekuće likvidnosti (CR), najveći dio varijacija je objašnjen samom promatranom varijablom. Međutim, za istaknuti je da sve do $24 \%$ varijacija te varijable objašnjava indikator rentabilnosti - ROE, što je u skladu s prethodno provedenim Grangerovim testom uzročnosti prezentiranim u Tablici 4. Pored toga, velik dio varijance tekuće likvidnosti (CR) se može objasniti i varijancom ubrzane likvidnosti (QR) što je logično se obzirom na međusobnu povezanost tih dvaju varijabli.

Jednako tako, sve do $27 \%$ varijance varijable QR objašnjava varijanca varijable ROE. S druge strane, čak 36\% varijance varijable QR je opisano varijancom tekuće likvidnosti, što je kako je prije navedeno i očekivano zbog povezanosti tih dvaju varijabli.

$\mathrm{S}$ aspekta varijanci indikatora rentabilnosti, veliku ulogu također ima varijanca ubrzane likvidnosti (QR). Tako, na primjer, varijanca varijable ROA je opisana najviše samom promatranom varijablom, ali i varijancom ubrzane likvidnosti sve do 33\%. S druge strane, varijanca varijable ROE u najvećem je omjeru opisana svojom varijancom, što je u skladu s rezultatima Grangerove uzročnosti prema kojima ne postoji signifikantna uzročnost prema Grangeru od varijable tekuće likvidnosti (CR) prema varijablama rentabilnosti ROA i ROE.

Kako bi se odredio smjer utjecaja varijabli, Slika 1. ilustrira ortogonalnu funkciju impulsnog odziva varijabli, a vrijednosti funkcije su prikazane u Tablicama 6., 7., 8. i 9. Rezultati funkcije dodatno potvrđuju Grangerov test kauzalnosti, ali i rezultate dekompozicije varijance. U slučaju indikatora rentabilnosti kao odzivnih varijabli na pozitivan impuls od strane varijable tekuće likvidnosti - CR (vrijednosti su prikazane u Tablici 6.), amplituda reakcije gotovo da i ne postoji, što dodatno potvrđuje nepostojanje uzročnosti prema Grangeru u tom istom smjeru, odnosno slabo opisanu varijancu indikatora rentabilnosti varijancom indikatora tekuće likvidnosti. U slučaju pozitivnog šoka od strane ubrzane likvidnosti - QR prema indikatoru rentabilnosti - ROA (vrijednosti prikazane u Tablici 7.), reakcija je negativna u prvom i drugom vremenskom intervalu, nakon čega se reakcija na impulsni šok smanjuje.

S druge strane, uslijed pozitivnog šoka od ubrzane likvidnosti - QR prema ROE, reakcija je pozitivna kroz prva tri perioda, nakon čega se vraća prema nultoj vrijednosti. Kada se promatraju indikatori likvidnosti kao odzivne varijable (prikazano u Tablici 8. i Tablici 9.), rezultati su također konzistentni s Grangerovim testom, odnosno dekompozicijom varijance. Može se uočiti da indikatori likvidnosti pozitivno reagiraju na impulsni šok od strane ROE indikatora. 
Slika 1.

\section{ORTOGONALNA FUNKCIJA IMPULSNOG ODZIVA}

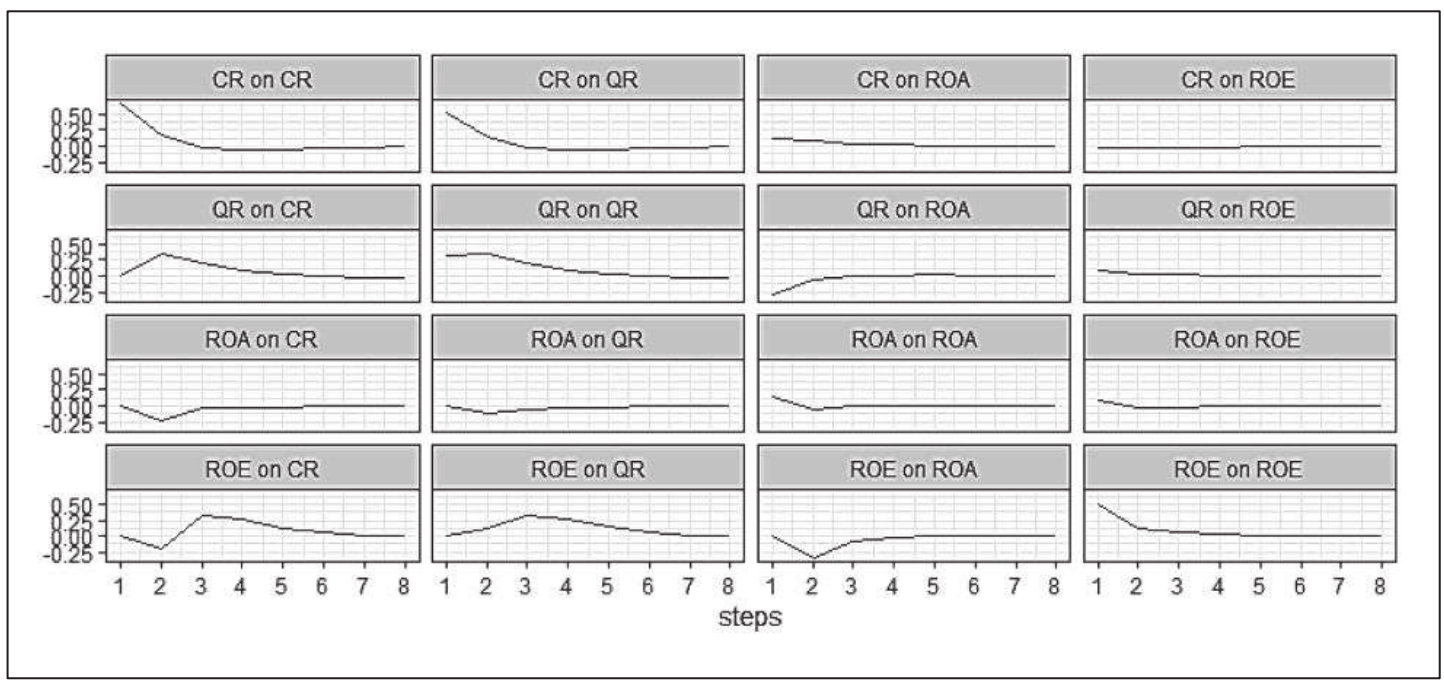

Izvor: Izrada autora

\section{Tablica 6.}

\section{VRIJEDNOSTI ORTOGONALNE FUNKCIJE IMPULSNOG ODZIVA ZA VARIJABLU CR}

\begin{tabular}{|c|c|c|c|c|}
\hline Broj koraka & CR & QR & ROA & ROE \\
\hline 1 & 0,68 & 0,51 & 0,13 & $-0,02$ \\
\hline 2 & 0,17 & 0,15 & 0,08 & $-0,02$ \\
\hline 3 & $-0,02$ & $-0,02$ & 0,04 & $-0,04$ \\
\hline 4 & $-0,05$ & $-0,06$ & 0,03 & $-0,03$ \\
\hline 5 & $-0,05$ & $-0,06$ & 0,01 & $-0,01$ \\
\hline 6 & $-0,04$ & $-0,04$ & 0,00 & 0,00 \\
\hline 7 & $-0,02$ & $-0,02$ & 0,00 & 0,00 \\
\hline 8 & $-0,01$ & $-0,01$ & 0,00 & 0,00 \\
\hline
\end{tabular}

Izvor: Izrada autora 
Tablica 7.

VRIJEDNOSTI ORTOGONALNE FUNKCIJE IMPULSNOG ODZIVA ZA VARIJABLU QR

\begin{tabular}{|c|c|c|c|c|}
\hline Broj koraka & CR & QR & ROA & ROE \\
\hline 1 & 0,00 & 0,31 & $-0,29$ & 0,09 \\
\hline 2 & 0,36 & 0,35 & $-0,04$ & 0,04 \\
\hline 3 & 0,22 & 0,21 & 0,02 & 0,02 \\
\hline 4 & 0,08 & 0,09 & 0,01 & $-0,01$ \\
\hline 5 & 0,02 & 0,02 & 0,02 & $-0,01$ \\
\hline 6 & $-0,01$ & $-0,01$ & 0,01 & $-0,01$ \\
\hline 7 & $-0,02$ & $-0,02$ & 0,01 & $-0,01$ \\
\hline 8 & $-0,01$ & $-0,02$ & 0,00 & 0,00 \\
\hline
\end{tabular}

Izvor: Izrada autora

Tablica 8 .

VRIJEDNOSTI ORTOGONALNE FUNKCIJE IMPULSNOG ODZIVA ZA VARIJABLU ROA

\begin{tabular}{|c|c|c|c|c|}
\hline Broj koraka & CR & QR & ROA & ROE \\
\hline 1 & 0,00 & 0,00 & 0,14 & 0,08 \\
\hline 2 & $-0,22$ & $-0,12$ & $-0,05$ & $-0,03$ \\
\hline 3 & $-0,03$ & $-0,05$ & 0,01 & $-0,02$ \\
\hline 4 & $-0,02$ & $-0,02$ & 0,01 & 0,00 \\
\hline 5 & $-0,02$ & $-0,01$ & 0,00 & 0,00 \\
\hline 6 & 0,00 & 0,00 & 0,00 & 0,00 \\
\hline 7 & 0,00 & 0,00 & 0,00 & 0,00 \\
\hline 8 & 0,00 & 0,00 & 0,00 & 0,00 \\
\hline
\end{tabular}

Izvor: Izrada autora 
A. ŠESTANOVIĆ, B. TOMIĆ, D. PUŠAR BANOVIĆ: Međuzavisnost rentabilnosti i likvidnosti primjenom panel VAR modela EKONOMSKI PREGLED, 72 (6) 894-919 (2021)

Tablica 9.

VRIJEDNOSTI ORTOGONALNE FUNKCIJE IMPULSNOG ODZIVA ZA VARIJABLU ROE

\begin{tabular}{|c|c|c|c|c|}
\hline Broj koraka & CR & QR & ROA & ROE \\
\hline 1 & 0,00 & 0,00 & 0,00 & 0,51 \\
\hline 2 & $-0,21$ & 0,13 & $-0,35$ & 0,13 \\
\hline 3 & 0,33 & 0,33 & $-0,10$ & 0,07 \\
\hline 4 & 0,26 & 0,26 & $-0,01$ & 0,04 \\
\hline 5 & 0,13 & 0,14 & 0,00 & 0,01 \\
\hline 6 & 0,06 & 0,06 & 0,01 & $-0,01$ \\
\hline 7 & 0,01 & 0,01 & 0,01 & $-0,01$ \\
\hline 8 & $-0,01$ & $-0,01$ & 0,01 & $-0,01$ \\
\hline
\end{tabular}

Izvor: Izrada autora

\section{ZAKLJUČAK}

Cilj istraživanja je empirijski potvrditi ili opovrgnuti međusobni kauzalitet varijabli rentabilnosti (prinos na ukupnu imovinu i prinos na vlastiti kapital) u odnosu na varijable likvidnosti (koeficijent tekuće likovnosti i ubrzane likvidnosti). Uzorkom su obuhvaćena nefinancijska društva uvrštena u barem jedan od dioničkih agregatnih ili sektorskih indeksa Zagrebačke burze s panel podatcima koje obuhvaćaju vremensko razdoblje od devet godina, počevši od 2009. godine do zaključno s obuhvatom 2017. godine. Istraživanje međusobnog kauzaliteta odabranih varijabli je provedeno metodološkim pristupom koji podržava panel formulaciju podataka. U tu svrhu u radu je proveden Granger-ov test uzročnosti, projekcija ortogonalne dekompozicije varijance i ortogonalna funkcija impulsnog odziva. Također, s obzirom na mogućnost postojanja kointegracije između promatranih varijabli, u radu je proveden test jediničnog korijena i test stabilnosti modela za sve pokrenute jednadžbe. Jednako tako, prilikom ugođavanja modela, definiran je i optimalni broj pomaka svih varijabli.

Rezultati testa jediničnog korijena, kao i stabilnosti modela za sve kreirane jednadžbe PVAR modela, sugeriraju da su varijable stacionarne u svojim razinama, odnosno u svom izvornom obliku te se, zbog toga, odbacuje mogućnost postojanja povezanosti između varijabli u dugom roku. S druge strane, prema Grangerovom testu uzročnosti za dani interval statističke značajnosti od 5\%, te optimalnim brojem pomaka koji iznosi 1, rezultati testa ukazuju na visoku uzročnost između pro- 
matranih varijabli u kratkom roku. Podatci pokazuju značajni međusobni kauzalitet promatranih varijabli osim utjecaja koeficijenta tekuće likvidnosti (kao uzročne varijable) na odzivne varijable - prinos na ukupnu imovinu (ROA) i prinos na vlastiti kapital (ROE). Utvrđuje se da rentabilnost društava promatran kroz prinos na ukupnu imovinu (ROA) i prinos na vlastiti kapital (ROE) značajno utječe na koeficijente tekuće i ubrzane likvidnosti. S druge strane, veća likvidnost društva mjerena koeficijentom tekuće likvidnosti ne pokazuje značajnu uzročnost na rentabilnost.

Rezultati ortogonalne funkcije impulsnog odziva varijabli u skladu je s rezultatima Grangerovog testa. Veća rentabilnost značajno pozitivno utječe na koeficijente tekuće i ubrzane likvidnosti. Značajan dio varijacija varijable tekuće i ubrzane likvidnosti objašnjava indikator rentabilnosti - ROE, što je u skladu s provedenim Grangerovim testom uzročnosti.

Može se zaključiti da se prihvaća alternativna hipoteza $H_{1}$ u dijelu kojem se potvrđuje signifikantna uzročnost varijabli rentabilnosti (ROE i ROA) na varijable likvidnosti (koeficijent tekuće likvidnosti i koeficijent ubrzane likvidnosti), no nije potvrđena signifikantna uzročnost varijabli likvidnosti (koeficijent tekuće likvidnosti i koeficijent ubrzane likvidnost) na varijable rentabilnosti (ROE i ROA). Navedeno istraživanje ukazuje da će veća rentabilnost značajno pozitivno utjecati na pokazatelje likvidnosti, dok veći koeficijenti likvidnosti ne utječu značajno na pokazatelje rentabilnosti.

Provedeno istraživanje, iako izvorno u naravi, provedeno je ipak na ograničenom uzroku (relevantnih) društava s razvijenom funkcijom financijskog menadžmenta, a rezultati su u skladu s očekivanjima autora. Tako dobiveni rezultati svakako sugeriraju potrebu daljnje verifikacije postignutih rezultata istom primijenjenom metodologijom na uzorku društava uvrštenih na inozemnim burzama, odnosno na širem zemljopisnom području.

\section{LITERATURA}

1. Ahmad, R. (2016) A Study of Relationship between Liquidity and Profitability of Standard Charterd Bank Pakistan: Analysis of Financial Statement Approach, Global Journal of Management and Business Research: C Finance, Volume 16, Issue 1, Version 1.0

2. Andrews, D. i Lu, B. (2001). ,Consistent Model and Moment Selection Procedures for GMM Estimation with application to dynamic panel data models." Journal of Econometrics, 101(1):123-164.

3. Baidh, M. L. (2013) Effect of Working Capital Management on Profitability of Company, Anusandhanika / Vol. V / No. I \& II/ 2013, pp. 247-251 
4. Baños-Caballero S., García-Teruel, P. J. and, Martínez-Solano P. (2014) Working capital management, corporate performance, and financial constraints, Journal of Business Research, 67, 332-328

5. Belak, V. (2014) Analiza poslovne uspješnosti. 130 ključnih pokazatelja performance i mjerila za kontroling, RRiF Plus d.o.o. Zagreb

6. Cristea, C. and Cristea M. (2016), The impact of the working capital management on firm profitability in the Romanian manufacturing industry, Annals of the University of Oradea, Fascicle of Management and Technological Engineering, Issue 2

7. Deloof, M. (2003) Does Working Capital Management Affect Profitability of Belgian Firms? Journal of Business Finance \& Accounting, 30(3) \& (4), April/May

8. Dickey, D. A., Fuller, W. A., (1979): „Distribution of the Estimators for Autoregressive Time Series With a Unit Root.“ Journal of the American Statistical Association,'74, str. 427-431.

9. Dumitrescu, E., Hurlin, C. (2012). ,Testing for Granger non-causality in heterogeneous panels.“ Economic Modelling, 29(4), 1450-1460. ISSN 0264-9993, http://www.sciencedirect.com/ science/article/pii/S0264999312000491.

10. Eljelly, A. M. A. (2004) Liquidity - Profitability tradeoff: An empirical investigaton in an emerging market, International Journal of Commerce and Management 14(2), 48-61

11. Falope, O.I. and Ajilore, O.T. (2009) Working Capital Management and Corporate Profitability: Evidence from Panel Dana Analysis of Selected Quoted Companies in Nigeria, Research Journal of Busiess Management 3 (3), 73-84

12. Gabrić, D. (2015) Istraživanje povezanosti profitabilnosti i likvidnosti kod poduzeća na tržištu kapitala u Federaciji BIH. VII međunarodna naučnostručna konferencija „Razvoj poslovanja 2015“, God 2, br. 1, Ekonomski fakultet Univerziteta u Zenici

13. Gill, A. Biger, N. and Mathur, N. (2010) The Relationshion Between Working Capital Management And Profitability: Evidence From The United States, Business and Economics Journal, Volume 2010: BEJ-10

14. Granger CWJ (1969). „Investigating Causal Relations by Econometric Models and Cross-spectral Methods." Econometrica, 37(3), 424-438. ISSN $00129682,14680262$.

15. Helfert, E. A. (1997) Tehnike financijske analize, Hrvatska zajednica računovođa i financijskih djelatnika, Zagreb

16. Hirigoyen, G. (1985) Les implications de la spécificité des comportements financiers des moyennes entreprises industrielles (M.E.I) familiales, Cahier de recherche, IAE de Toulouse, $n^{\circ} 35$ 
17. Korent, D. and Orsag, S. (2018) The Impact of Working Capital Management on Profitability of Croatian Software Campanies, Zagreb International Review of Economics \& Business, Vol 21, No 1, pp 47-65

18. Lazaridis, I. and Tryfonidis, D. (2006) The relationship between working capital management and profitability of listed companies in the Athens Stock Exchange, Journal of Financial Management and Analysis, Vol. 19, No. 1, January-June

19. Levin A, Lin C, Chu C (2002). „Unit root test in panel data: asymptotic and finite sample properties." Journal of Econometrics, 108, 1-24.

20. Lutkepohl, H. (2007). New Introduction to Multiple Time Series Analysis. Springer-Verlag Berlin Heidelberg, 2 edition.

21. Mamić Sečer, I., Tušek, B. i Korica, I. (2013) Empirijska analiza utjecaja likvidnosti na profitabilnost hrvatskih srednjih i velikih poduzeća u grani djelatnosti informacije i komunikacije, Zbornik Ekonomskog fakulteta u Zagrebu, godina 11, br. 2

22. Morris, J.R. and Daley, J.P. (2009) Introduction to Financial Models for Management and Planning, CRC Press, Taylor \& Francis Group, London

23. Orsag, S. (2011) Vrijednosni papiri: Investicije i instrumenti financiranja, Revicon, Sarajevo

24. Orsag, S. (2015) Poslovne financije, HUFA i Avantis, Zagreb

25. Pfaff, B. (2008). „VAR, SVAR and SVEC models: Implementation within $r$ package vars." Journal of Statistical Software, 27(4).

26. Raykov, E. (2017) The liquidity-profitability trade-off in Bulgaria in terms of the changed financial management functions during crisis, Management, Vol. 20, 1 , pp 135-156

27. Richards, V.D and Laughlin, E.J. (1980) A Cash Conversion Cycle Approach to Liquidity Analysis, Financial Management (pre-1986); Spring 1980; 9, 1; ProQuest Central, pp. 32

28. Serdarušić, H. (2007) Utjecaj financijskog položaja i aktivnosti na novčani jaz i profitabilnost hrvatskog turističkog sektora (magistarski rad), Ekonomski fakultet u Zagrebu, Zagreb

29. Shim J. K. and Siegel, J. G. (2007) Upravljačke financije, Zgombić \& Partneri d.o.o., Zagreb

30. Shin, H. H. and Soenen, L. (1998) Efficiency of Working Capital Management and Corporate Profitability, Financial Practice and Education, Vol. 8, No. 2, pp 37-45

31. Sigmund, M. i Ferstl, R. (2017). „Panel Vector Autoregression in R with the package panelvar.“ Available at SSRN: https://ssrn.com/abstract=2896087 
32. Sorić, I. (2002) Analiza povezanosti između poslovnog rezultata i likvidnosti, Ekonomski pregled, 53 (9-10, str. 921-933

33. Stjepanović, S. i Cita, M. (2016) Međuzavisnost poslovnog rezultata i pokazatelja likvidnosti hrvatskih poduzeća iz prehrambene djelatnosti, Međunarodna naučna konferencija Univerziteta Singidunum, Finiz 2016, str 175-180

34. Svitlík J. and Poutník L. (2016) Relationship between Liquidity and Profitability: Empirical Study from the Czech Republic, European Financial and Accounting Journal, 2016, vol. 11, no. 3, pp 07-24

35. Tušek, B., Perčević, H. i Hladika, M. (2014) Međuovisnost novčanog jaza i profitabilnosti u hotelskoj industriji u Republici Hrvatskoj, Acta Turistica, Vol 26, No 1, pp 55-75

36. White G.I., Sondhi A.C. and Fried, D. (1994) The Analysis and Use od Financial Statements, John Wiley and Sons, Inc, USA

37. Wolski R. and Bolek, M. (2016) Liquidity - Profitability Relationship Analysed Once Again. The Case of Poland, European Scientific Journal, March 2016, vol. 12, No 7, pp 33-46

38. Žager L., Žager K. (2008) Analiza financijskih izvještaja, Masmedia, Zagreb

\section{INTERDEPENDENCE OF PROFITABILITY AND LIQUIDITY USING THE PANEL VAR MODEL}

\section{Summary}

The aim of the research is to empirically verify the interdependence of company profitability and liquidity. The sample includes twenty non-financial corporations listed in at least one of the Zagreb Stock Exchange sector indices. The panel data cover a period of nine years, starting in 2009 and ending in the 2017. The verification of the mutual causality has been conducted using Granger's causality test adapted to the panel data. The panel vector autoregression model has been applied with analysis of the structure model: orthogonal decomposition of variances of prognostic errors and analysis of the orthogonal function of impulse responses. The results show a significant causality of the profitability variables (return on total assets and return on equity) on current and accelerated liquidity ratios. On the other hand, no significant causality of liquidity ratios on profitability variables has been verified. The results are in line with the expectations from financial theory that the significant liquidity in a company per se does not have a significant impact on profitability. This research was conducted on a limited sample of listed companies on the Zagreb Stock Exchange. This suggests the implementation of similar research on a wider sample of companies listed on other stock exchanges to verify the obtained results. The originality of the research lies in the comprehensive systematization of earlier papers that investigated the causality of profitability and liquidity. In addition, the original approach to testing the mutual causality of variables liquidity and profitability using more complex statistical analysis tools has been applied.

Key words: profitability, liquidity, return on equity, return on assets, panel VAR model 